\title{
Environmental Valuation of Investment Projects With Point of 'Production Approach':Korudanlık Gold-Silver Mine Project in Turkey.
}

\author{
Dr. Alper DEMIRBUGAN \\ MTA General Directorate, Ankara-Turkey \\ ademirbugan@yahoo.com
}

\begin{abstract}
Monetary valuation of changes in environmental quality has a great importance in evaluation of investment projects. The benefit or avoided damage cost from a project to change environmental quality is captured by individuals' wilingness to pay(WTP). Valuation methods based on WTP can mainly be categoriesed in two groups as 'production approach' and 'utility approach'. In this study, concept of wilingness to pay and valuation methods based on 'production approach' are investigated with an application to a mine project in Turkey.
\end{abstract}

Key Words: Willingness to Pay, Environmental Valuation, Opportunity Cost Method, Mining.

Academic Disipline and Sub-Disciplines :

Economy

\section{SUBJECT CLASSIFICATION}

Library of Congress Classification:Subclass HB:Economic Theory, Demograpy.

\section{TYPE(METHOD/APPROACH)}

Theorising, review of Literature, quantitative application

\section{INTRODUCTION}

Investment projects have important effect on the local and global environment. Typical environmental impacts are associated with local air quality, climate change, water quality, soil and groundwater quality, biodiversity and landscape degradation. A decrease or increase in the quality or quantity of environmental goods and services will produce some changes in social benefits. Not taking into account environmental impacts will result in over or underestimation of the social benefits of the project and will lead to bad economic decisions. In environmental evaluation methods, the environmental benefit or avoided environmental damage originating from the project is mostly determined based on the willingness to pay (WTP) of the individuals. Willingness to pay with a broad definition is the amount that individuals are willing to pay to buy a good or to avoid from the negative effect of that good(Metcalfe and Baker, 2015; Hailwood, 2015; European Union, 2008; Bennet, 2011). The determination of WTP requires for knowing the demand structure and market prices. But for environmental services it is difficult directly to determine WTP by the costs formed as a result of marketing mechanism. Therefore; during the evaluation process of environmental effects the methods related to the determination of WTP directly and indirectly have been developed. These methods can be divided into two main categories as "utility approach" and "production approach". In methods of "utility approach", which is also called as the "demand curve approach", basically; the demand structure is analyzed in order to determine the social benefit of an environmental active. In methods of "production approach", which is also called as "supply side approach", the social benefit of the environmental factors is studied by associating the changes in environmental quality with that of changes in production changes. In production approach methods, WTP is indirectly determined. Main methods based on production approach are the methods of dose-response, preventive cost and opportunity cost.

In this study, the environmental evaluation methods based on the production approach were investigated, and the opportunity cost method and its application type, which is called as the "threshold analysis", was applied in Korudanlık Gold-Silver Mine project in Turkey as an example.

\section{WILLINGNESS TO PAY AND PRODUCTION APPROACH}

Environmental valuation is based on people's willingness to pay. WTP is the maximum amount individuals are prepared to pay for a environmental good and service( (Greenstone, 2015). WTP is measured by demand price at the margin. Viewed this way, decision making based on willingness to pay reflects individual's preferences for the environmental good in in questions. Social benefit aroused from changing of environmental quality can be examined on an example of emission reduction project (Hussen, 2005,144). It is assumed that the specific project under consideration is a government mandate to control sulphur emissions from electric power plant. In this case, the benefit is a direct result of improved air quality or the environmental demage avoided as a result of sulphur emissions. Benefit of this nature are measured by using a demand curve as shown in Figure 1. Suppose point $A$ on the demand curve represent the situation that prevailed before the project was initiated. Before legislative mandate, individuals were willing to pay price $t_{1}$ to avoid the last unit of sulphur emission, $Q_{1}$. Now, suppose that due to the new government initiative, sulphur emission is reduced from Q1 all the way to $Q_{2}$. That is, with the stricter sulphur pollution control, society is allowed to move from point $A$ to $B$ along its demand curve for environmental quality. At the new position, point $B$, individuals are willing to pay the price $t_{2}$ in order to avoid the last unit of emission, i.e.Q. $Q_{2}$. Given this, total social benefit of this project is examined. This total benefit is represented by the area under demand curve-area $Q_{1} A B Q_{2}$, which represents the sum of society's willingness to pay for moving from its initial position, point $A$ to the new position point $B$.
2098 | P a g e
council for Innovative Research 


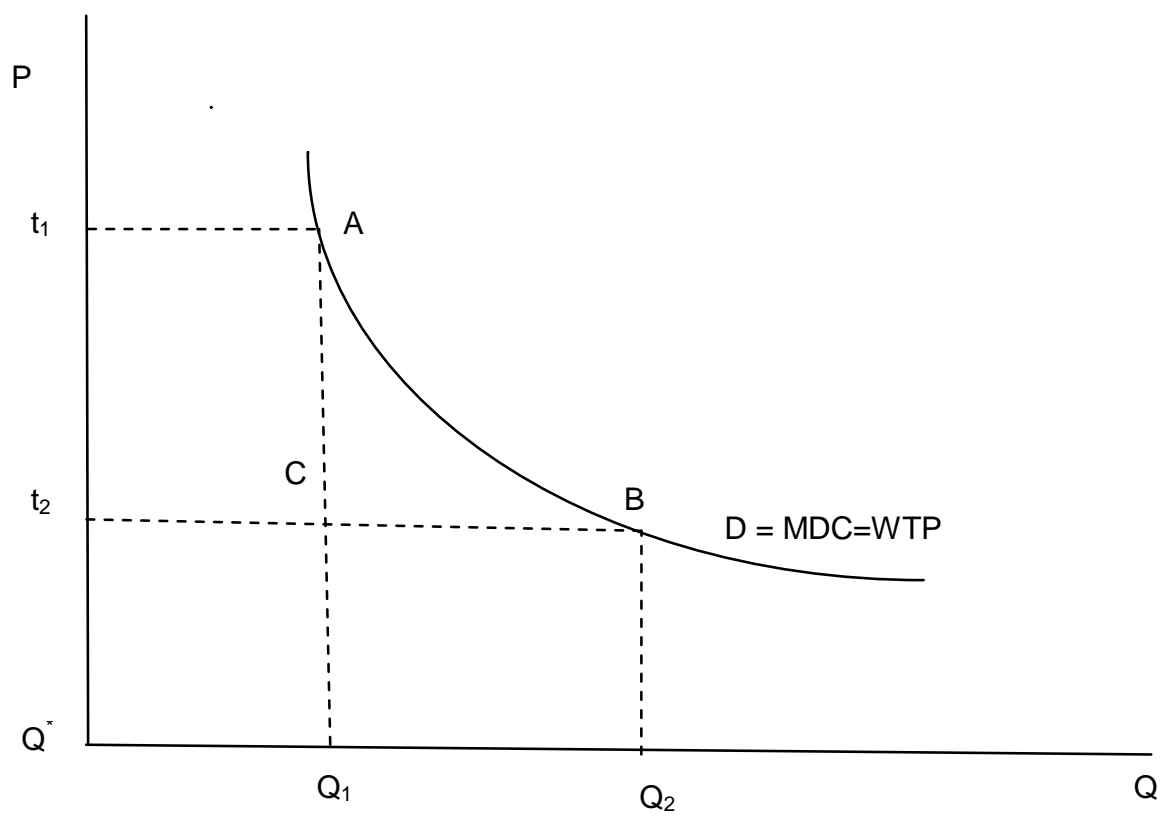

Figure 1: Changes in environmental quality and willingness to pay

In production approach changes in environmental quality are associated with changes in production level. 'Production methods' are based on the cost incurred due to changes in productivity, cost of avoiding damages, , the cost of providing substitute services and cost incurred due to foregone benefit, i.e. opportunity cost. In these methods changes in environmental quality is valued by indirect way.

The net benefit of a investment project, D, involving an environmental cost can be written below(Campbell and Brown, 2005,269).

$$
\mathrm{NB}(\mathrm{D})=(\mathrm{B}-\mathrm{C})-\mathrm{EB}
$$

Burada; $\mathrm{B}=$ the benefits of development project

$\mathrm{C}=$ the cost of development project

$\mathrm{EB}=$ the environmental cost of the project, measured as the forgone benefits resulting from the decline in quantity or quality of environmental resource.

Following the production approach, mainly, there are three types of methods for taking account of environmental cost, EB: the dose-response method assesses the forgone environmental benefits by the resulting decline in value of output in the economy ; the preventive cost method involves working out the cost of preventing or mitigating the environmental demage If the project goes ahead; and opportunity cost method involves working out the cost of preventing the environmental demage by modifying or forbidding the proposed development project(Campbell and Brown ,269).

\section{DOSE - RESPOND METHOD}

The dose-response method estimates value by measuring the contribution of the environmental resource to the output of those who rely on it for the production of goods or services. Dose - response function consists a useful technique which enable us to measure the relationship between a unit concentration of a pollutant and its impact on relevant receptor. Dose -response techniques are used extensively where a physical relationship between some cause of demage, such as pollution, and a environmental impact is known and can be measured. Once the relationship has been estimated, then willingness to pay measures derived from either market or efficient prices(Konstantinos and Karydis, 2004; Hanley and Spash, 1995). The major drawback of this technique is the main source of uncertainty that involves the specification of the dose-response function, which is crucial to its accuracy. This method can be used whenever the physical and ecological relationship between a pollutant and its application are known.

\section{PREVENTIVE COST METHOD}

The preventive cost method of measuring the cost of environmental demage assumes that the value of the environmental resource is equal to the cost of preventing or mitigating the environmental demage, or replacing or restoring the environmental asset, or relocating the environmental activity. When the quality of an environmental service deteriorates, households react to prevent or mitigate the effects. The method is applicaple in situations where households spend money to offset environmental impacts. It requires data on the environmental change and its associated substitution effects. The main advantages of this method is the relatively modest data requirements and the fact that provides estimations based on actual expenditures( (Pearce and Howardh, 2000; Konstantinos and Karydis, 2004). 


\section{ISSN $2321-1091$ \\ Volume $10 \mathrm{Number} 3$

\section{OPPORTUNITY COST METHOD}

Opportunity cost of a natural resource is the value of the next highest valued alternative use of that resource. For a natural area this may be agricultural use, use as a road and in some cases economic development. The opportunity costs of nature thus will depend largely on location and productivity. So, in different economic and spatial situations, the same ecological values can be valued differently in money terms(Jantzen, 2006). The main problem with this method is that it probably overestimates the value of nature, as the price is based on the next best economical use of land. It can be argued that the economic use of the land instead of nature, adds value to the land, so the value of natura would be lower. Opportunity cost method does not give an indication of how much lower. Value additive capacity of nature might be called as natural capital. On the other hand, opportunity cost method assumes that incurring a prevent or replace produces a benefit at least as great as the value of the environmental cost, or loss of benefit to society. This could be considered a reasonable assumption when the cost is incurred by private individuals or conservation groups, and when the objective is to assess the value to those individials or groups. This method become a lot less acceptable when used to estimate the value of benefits to society as a whole.

To make up for the deficiency, 'threshold analysis' is suggested. Threshold analysis investigates minimum social value of an natural resource taking account alternative proposals and natural capital. As stated in (Demirbugan, 2014), Campbell and Brown(2005:271) explains theoretical frame of threshold analysis with help of an model. In this model it is supposed that the government was considering an application for a development project that would involve degradation of wetland. The wetland plays an important role in the provision of ecosystem services, such as breeding habitat for some rare species of birds. To replace the wetland elsewhere is estimated to cost of $\mathrm{K}$. The development project is expected to generate a net income in net present value, $N P V_{P}$. If the same capital was invested elsewhere it would generate net benefit, $N P V_{a}$, implying that the contribution of the wetland's natural capital is $N P V_{N C}\left(N P V_{P}-N P V_{a}\right)$. Net present value of natural resource service is denoted by B. In this model, what would the present value to society of the wetland's ecosystem services, denoted by $B$ is investigated taking into account investment alternatives. Alternatives are given below;

Alternative 1: To preserve the wetland intact, not allowing the project to proceed.

Alternative 2: To allow the project to proceed provided the wetland is replaced elsewhere.

The answer to these questions involves choosing among two mutually exclusive projects. Appropriate decision rule is to choose the project with the highest NPV. If the project does not proceed(alternative1), the manufactured capital invested elsewhere will yield an net present value denoted by $\mathrm{NPV}_{\mathrm{A}}$ and the wetland will yield an net present value of $\mathrm{B}$. Thus, present value of net benefit aroused from alternative1 is $\mathrm{NPV}_{A}+\mathrm{B}$. If the project proceeds with replacement (alternative2), net present value is $N P V_{P}+B-K$. Options related to minimum value of natural resource service taking into account investment alternatives can be examined with help of inequalities given below.

Alternative 1:

$\mathrm{NPV}_{\mathrm{A}}+\mathrm{B}>\mathrm{NPV}$, that is; $\mathrm{B}>\mathrm{NPV}_{\mathrm{NC}}$

and

$$
\mathrm{NPV}_{\mathrm{A}}+\mathrm{B}>\mathrm{NPV}_{\mathrm{P}}+\mathrm{B}-\mathrm{K} \text {, that is } \mathrm{K}>\mathrm{NPV}_{\mathrm{NC}}
$$

Alternative 2:

$$
N P V_{B}+B-K>N P V_{A}+B \text {, that is; } K<N P V_{N C}
$$

and

$$
\mathrm{NPV}_{\mathrm{P}}+\mathrm{B}-\mathrm{K}>\mathrm{NPV} \text {, that is } \mathrm{B}>\mathrm{K}
$$

When $\mathrm{K}<\mathrm{NPV}_{\mathrm{NC}}$ alternative1 immediately rules out.

\section{CASE STUDY: KORUDANLIK MINE PROJECT IN TURKEY}

The theoretical approach related to the prediction of minimum social value of environmental resources can be applied on 'Korudanlık Gold - Silver Mine Project'in Turkey, when alternative investment proposals are in question.

Korudanlık gold - silver deposit is taken place in Bilecik province located $300 \mathrm{~km}$ west to Ankara in Turkey. With Korudanlık project, the production of ore reserve consisting of 1300000 tons of gold-silver is planned. The average tenures for gold and silver are $3.86 \mathrm{gr} / \mathrm{ton}$ and $1.13 \mathrm{gr} / \mathrm{ton}$, respectively. It is planned to take out the mineral deposit at the end of 2.5 years production period in such a way to produce 4.2 tons of gold ingot and 1.2 tons of silver ingot. Present value of the project has been estimated as 61 million $\$$ according to adjusted data to 2015 by accepting 1 ounce of gold and 1 ounce of silver as $1100 \$$ and $13 \$$, respectively. The natural resource affected from the project is the terrigenous ecosystem in which 2900 ha. mine area is located. This ecosystem is represented by mixed oak forests in which agricultural area are hosted. The fauna comprises various mammals, bird, reptile and dual life species (ENCON, 2012, 3436).

Parameters used in the prediction of minimum value which the natural resource could intake can be summarised as below; 
The net benefit of the project $\left(N P V_{P}\right)$, that is the total present value of cash flows which project yields during its lifetime is 61 million $\$$. The investment amount is 40 million $\$(E N C O N, 2012,34)$.

The alternative benefit $\left(\mathrm{NPV}_{\mathrm{A}}\right)$ of the investment capital that will form by being valued 2.5 years in the bank by 0.025 annual interest rate applied to foreign currency deposits by the Central Bank(T.C. Merkez Bankası, 2015).

$40000000 \$(1.025) 2.5=42.5$ million $\$$

The contribution of the natural capital to the project $\left(\mathrm{NPV}_{\mathrm{NC}}\right)$;

61 million $\$-42.5$ million $\$=18.5$ million $\$$

The agricultural field located in Korudanlık ecosystem is 1740 ha. The mean unit replant cost of such an area is 3000 $\$$ (Ministry of Food, Agriculture and livestocks, 2015)(www.tarim.gov.tr). The cost of forming total agricultural field is;

$3000 \$ /$ ha * 1740 ha $=5160840 \$$

The forest area is 1160 ha. The cost of unit reforestation is $1800 \$ /$ ha. (Ministry of Forestry and Water Affairs, 2015). Total cost is;

$1800 \$ /$ ha. ${ }^{*} 1160$ ha. $=2088000 \$$

Total reproduction cost of agricultural and forest areas in Korudanlık ecosystem(K) is;

$5220000 \$+2088000 \$=7308000 \$=7,30$ million $\$$.

There are two alternative investment proposals for Korudanlık area. These are preserving the natural resource intact not allowing the project to be applied(alternative1) or to apply the project also by replacing the natural resource elsewhere(alternative2).

The realisation conditions of alternatives associated with the minimum value of the environmental resource(B) explained in theoretical model for Korudanlık project can be investigated as below;

Alternative1:

42.5 million $\$+B>61$ million $\$$, that is; $B>18.5$ million $\$$

and

45.2 million $\$+B>61$ million $\$+B-7.19$ million $\$$, that is

7.30 million $\$<18.5$ million $\$$

Alternative 2:

61 million $\$+B-7.30$ million $\$>42.5$ million $\$+B$, that is;

7.30 million $\$<18.5$ million $\$$

and

61 million $\$+B-7.30$ million $\$>61$ million $\$$, that is;

$\mathrm{B}>7.30$ million $\$$

In the case of not applying the project by preserving the natural resource, $\mathrm{K}$ should be greater than NPV $\mathrm{NC}_{\mathrm{N}}$ As for the Korudanlık example, $\mathrm{K}$ is less than $\mathrm{NPV}_{\mathrm{NC}}(7.30$ million $\$<18.5$ million $\$)$. Thus, alternative 1 is eliminated. In case, when the natural resource is replaced and the project is applied, conditions of ( $\mathrm{K}<\mathrm{NPV}$ NC.) and $(\mathrm{B}>\mathrm{K})$ are satisfied. Values related to these conditions for Korudanlık Project are repectively, $(7.30$ million $\$<18.5$ million $\$)$ and $(B>7.30$ million $\$)$. So, alternative2 can be applied. The minimum value of the environmental source is 7.30 million $\$$ in the Korudanlık area.

\section{RESULTS}

The environmental benefit or avoided cost should be calculated by revealing the willingness to pay(WTP) of individuals for marginal changes in the environmental quality. The changes in environmental quality in 'production approach' are associated with changes in production relations which hosts the willingness to pay. The main methods based on the production approach are dose-response, preventive cost and opportunity cost methods. In this study, concept of willingness to pay and the environmental valuation methods based on the production approach are considered in theoretical framework, and the threshold analysis, which is a type of opportunity cost method, is applied on Korudanlık Gold - Silver Mine Project.

The environmental benefit lost in methods based on dose-response approach is measured by the decrease in the output level. In the opportunity cost method, The cost of change in environmental quality is investigated for different application types of the investment projects. The preventive cost method consists of the determining the cost of elimination of environmental damage or prevention. 


\section{ISSN $2321-1091$ \\ Volume $10 \mathrm{Number} 3$ \\ Journal of Social Sciences Research}

In methods based on the production approach, costs incurred by persons or groups in order to protect the environmental resource or to avoid from destruction or to remediate are accepted as the environmental cost or the social benefit lost. But the minimum benefit of the change in the environmental quality for the whole society can be determined by threshold analysis considering alternative projects.

The threshold analysis related to the determination of the minimum value of the environmental resource associated with various investment alternatives was applied to the Korundalık project. The investment alternatives for the Korundalık project are not to apply the project but to preserve the available ecosystem and to realize the mining project by replacing the ecosystem elsewhere. The alternative consisting of the application of mining project provides a higher net profit. Therefore, the minimum or the threshold value for the environmental resource was predicted as 7.30 million $\$$.

\section{REFERENCES}

1. Bennet, J. 2011. The International Handbook on Non Market Environmental Valuation. Cheltenham,U.K.: Edward Elgar Publishing.

2. Campbell, H., and Brown, R. 2005. Benefit-Cost Analysis:Financial and Economic Appraisal Using Spreadsheeds. Cambridge University Press.

3. Demirbugan, A. 2014. Valuation Methods of Environmental Effects of Mining. Çankırı Karatekin University Journal of the Faculty of Economics and Administrative Sciences, 287-300.

4. ENCON. 2012. Korudanlık Golden-Silver Open Mine Project Environmental Impact Assesment Report. Ankara.

5. European Union. 2008. Guide to Cost Benefit Analysis of Investment Projects. European Commission Directorete General Regional Policy.

6. Greenstone, M. 2015. 'Envirodevenomics:A Research Agenda for an Emerging Field'. Journal of Economic Literature, 53(1), 5-42.

7. Hailwood, S. 2015. Alienation and Nature in Environmental Philosopy. Cambridge: Cambridge University Press.

8. Hanley, N., and Spash, C. 1995. Cost Benefit Analsis and the Environment. Edward Elgar.

9. Hussen, A. 2005. Principles of Environmental Economics. Routledge.

10. Jantzen, J. 2006. The Economic Value of Natural and Environmental Resources. Nedherland: Institute for Applied Environmental Economics.

11. Konstantinos, G., and Karydis, V. 2004. 'Combination of Monetary Valuation Techniques and Application to Environmental İmpact Receptors'. Fresenius Environmental Bulletin, 283-288.

12. Metcalfe, P., and Baker, W. 2015. The Sesitivity of Willingness to pay to an Economic Downturn. Journal of Environmental Economics and Policy. 4(1).

13. Ministry of Food, Agriculture and Livestocks.2015. Production Statistics. Ankara.

14. Ministry of Forestry and Water Affairs. 2015. Unit Price Tables. Ankara: General Directorete of Combating Desertification and Erosion.

15. Pearce, D., and Howardh, A. 2000. Technical Report on Methodology:Cost Benefit Analysis and Policy Responses. Bilthoven: National Institute of Public Health and The Environment.

16. T.C. Merkez Bankası. 2015. Maximum Interest Rates for Foreign Currency Accounts. Ankara. 